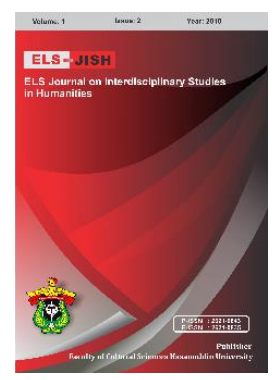

ELS-JISH

ELS Journal on Interdisciplinary Studies on Humanities

Volume 1 Issue 2, 2018

ISSN (print) : 2621-0843

ISSN (online) : 2621-0835

Homepage : http://journal.unhas.ac.id/index.php/jish

\title{
The Use of Modalities in Indonesian Divorce Mediation Discourse
}

\author{
Andi Batari Andisa Putri ${ }^{1 *}$, Hamzah Machmoed ${ }^{2}$, Sukmawaty ${ }^{3}$ \\ *e-mail of Corresponding Author: andisaputri429@gmail.com
}

\begin{abstract}
Language is more than just a tool of communication. Beyond, it is a window to see how people organize their understanding and expression of conflict, including in a divorce. Divorce mediation then can be an alternative for dispute resolution process. The speakers' (spouses and mediator) judgment and attitude towards the topic discussed in divorce mediation are implied in language they use in making statement, response or feedback related to the problems. It deals with one of linguistic features known as Modality. This research therefore, aims to identify the modalities used by Indonesian speakers in divorce mediations and to explain their attitude toward the problems discussed in divorce mediations and toward interlocutors. The research was conducted using Halliday's theory of Modality. The result of this research shows kinds of modalities used by Indonesian speakers in divorce mediations discourse; specifically in the type, orientation, and the value of modality. The mediator mostly used probabilities and the wife mostly used inclinations. Besides, the mediator and husband mostly used low value modalities. Furthermore, in Indonesian divorce mediation discourse, the mediator, husband, and wife mostly used subjective-implicit. The topic discussed in Indonesian divorce mediation is about reuniting the husband and wife who planned to have a divorce.
\end{abstract}

Keywords: : Modalities, Divorce Mediation Discourse

How to cite: Putri, A, B, A, et al. (2018). The Use of Modalities in Indonesian Divorce Mediation Discourse. ELS Journal on Interdisciplinary Studies in Humanities, 1 (2), 126-133.

\section{Introduction}

Language is more than just a tool of communication. Beyond, it is a window to see how people organize both their understanding and expression of conflict. Taking a look at interpersonal relationship within society, divorce is one example of conflicts that is when a man (husband) and a woman (wife) as a couple in a marriage life are failed to solve their problems by themselves and then managed to separate. As one of alternatives to solve the problem, a conflict resolution or best known as a divorce mediation then can be conducted. According to Casals (2005:1) in his journal of Comparative Law, divorce mediation can be defined as a dispute resolution process in which the spouses are assisted by an impartial and neutral professional (the mediator) in order to analyze the situation arising from divorce and try to reach their own agreement with regard to some or all of the matters under dispute. When it comes to a matter of what is happening in this process, language use is one of the aspects that should be analyzed. The discussion under the field of linguistics then needs to be conducted as it may influence the process of divorce mediation until final decision making. In this process, the mediator should understand the importance of controlling his/her language in order to modify how the

\footnotetext{
${ }^{1,2,3}$ Faculty of Cultural Sciences, Hasanuddin University 
conflict is resolved (Foster:2003,3). The speakers' (spouses and mediator) judgment and attitude towards the topic discussed in divorce mediation are implied in language they use in making statement, response or feedback related to the problems. This notion deals with one of linguistic features known as modality. Modality refers to the speaker's judgment toward a proposition he/she makes as it is clearly stated by Gurbanova (2012:1) that modality is a semantic-grammatical category which expresses the attitude of the speaker to the discourse. In other words, it indicates the level of speakers' commitment toward the proposition of their utterances. It helps the speakers to express their attitude in order to persuade others in the form of inclination, allowing, permission, keen, obligation or willing. Modality also can represent possibility, probability and certainty related to the truth or possibility in representing a reality. It directly represents uncertainty of meaning. Therefore, modality is used to construe the things in between the negative or positive fact. It means modality reflects the belief (or the doubt) of the speaker to his/her proposition. Besides, since the Indonesian language of South Sulawesi has unique characteristic that is different from standard Indonesian language, the study of modalities is then interesting to be conducted to find out how they are constructed in divorce mediation. Therefore, the researcher decides to conduct the research about The Use of Modalities in Indonesian Divorce Mediation Discourse.

There have been very few researches on divorce mediation, mostly are on the field of Law. One of the researches is a research conducted Kruk (1998) entitled Imbalance and spouse abuse in divorce disputes: deconstructing mediation practice via the 'simulated client' technique. The research examined how mediators respond in situations of power imbalance and spouse abuse, and their choice of a neutralist versus interventionist mediator approach in handling these cases. Meanwhile, there is only one research on the Linguistics field with divorce mediation discourse as its object. It is a dissertation written by Hill (2007) entitled "A Pragmatic Analysis on Family Mediation". It analyzes the verbal enactment of mediator impartiality and neutrality, and of power and politeness by both clients and practitioners. In other side, there are several previous studies on modalities, almost in political discourse and others in texts. Firstly, Adawiah (2014) conducted her study in political debate by investigating the interpersonal function and also speakers' attitude toward the topic and the other speakers. Secondly, Kristianto (2014) conducted his study by investigating the use of modality in terms of its potential reflection on the power distribution in the text. The texts, as the discourse, are the editorials issued in 1992 by The Jakarta Post, an Indonesian English newspaper.

Third, Roth (2014) conducted her study by investigating the power, politics, and gender-related epistemic modality in TV/videos interview with Canadian politicians. The study examined usage, distribution and function of gender-related epistemic modality in the form of hedges and boosters in political interviews. Fifth, Rahman (2015) conducted his study by investigating the schematic structure and modality used in preaching discourse of Sanusi Baco, L.C. The findings are that in its schematic structure, the preaching aims to explain, describe and share to the listeners the information related to the topic pilgrimage in Islam, belief and good deeds, and Isra' Mi'raj phenomenon.

Since the Indonesian culture is diverse, this research therefore, aims to identify the modalities used by Indonesian speakers of South Sulawesi in divorce mediations and to explain their attitude toward the problems discussed in divorce mediations and toward interlocutors. The language is quite different from standard one, so it is interesting to see how the use of modalities in their speaking. The research was conducted using Halliday's 
theory of Modality and the research is eager to question the universality of the theory by seeing its use in Indonesian divorce mediation in South Sulawesi.

\section{Method}

This research uses descriptive qualitative method in order to obtain an accurate profile of the Indonesian speakers in South Sulawesi and their use of modality in their speaking in divorce mediation.

\subsection{Source of Data}

The data in this research is taken based on the observation results and recordings of divorce mediation in Islamic Court of Masamba in North Luwu regency, South Sulawesi

\subsection{Data Collection}

To collect Indonesia data, the researcher recorded the divorce mediation process in a court. It was recorded candidly by using smart phone's recorder. It is done candidly, to keep the divorce mediation run naturally. The researcher had asked permission to mediators to join the divorce mediations after getting an approval by the Head of Islamic Court of Masamba, North Luwu to conduct the research. After the divorce mediation finished, the researcher then told the spouses that their mediation process had been recorded as the data for research purpose. They are asked whether they agree or not to be the object of the research. After getting their approval, the collected recording is then transcribed, ready to be the source of data. By applying purposive sampling, the researcher chose those which contain modality to be analyzed.

\subsection{Data Analysis}

The researcher uses some steps on analysis, as follows: 1) the recording was transcribed and translated into English as the research was conducted as the object of English Language Studies. 2) Modalities are identified and categorized based on the classification of modality from Halliday (1985) and they are shown in table. 3) Through modalities used by Indonesian speakers in divorce mediations, the speakers' attitude that is affected by local culture can be interpreted

\section{Findings}

All modalities data in these findings are classified by the categorization of Halliday (2004) where he actually examined modalities into the part of interpersonal meaning. Interpersonal function/meaning (tenor of discourse) means using (the function of) language to interact with each other, i.e. to encode our interaction, and to show how defensible we find our propositions (finite/auxiliary/modals). Based on his classification, the types modality are divided into modalization and modulation. Modalization is the term used to express indicative mood, i.e. probability and usuality. Modulation is the term used to express imperative mood, i.e. obligation and inclination.

Based on the speaker's orientation, Halliday (1985:336) explained that modalities are divided into subjective (explicit-implicit) and objective (explicit-implicit). The indicator to observe whether the modality is explicit or implicit is by determining the use of pronoun ' $l$ ' or 'we' as the subject of utterances. When the speakers use 'l' and 'we' as the subject, it is categorized as subjective explicit. While subjective implicit use other words which do not refer to the speakers' selves, such as - she, he, they, and so on.

And then, modalities can also be categorized by their values in which Halliday divided the value of modality into three, they are; high, median and low. First, high value 
refers to the high belief of speakers toward the topic, so it has 'positive' or 'yes' sense, for example in the utterance - 'I must be there'. Second, median (middle) value plays the sense between 'yes' or 'no', for example; 'I will be there'. Third, low value implies to the 'negative' or 'no' sense toward the topic, for example- 'I may be there'. In fact, in deciding of modalities value, the researcher should pay attention on the context of utterances, bring the text closer to the reality.

From the data, researcher finds out that the mediator used many types of probability in her utterances where the subjective implicit is in the highest frequency. In fact, there are 28 probabilities, 5 usualities, 11 obligations and 15 inclinations in mediator's utterances. The great number of probabilities shows that the mediator tried to express her indicative mood or her own thinking toward the problems discussed during divorce mediation and to respond the spouses' comments. The research also shows that the most significant of mediator's orientation is subjective implicit with 42 data, followed by 10 data of objective (explicit), 6 data of subjective (explicit) and 2 data of objective (implicit). In addition, there are 27 low value, 13 median value and 19 high value modalities.

Meanwhile, husband (who proposed a divorce) used many types of usuality in his utterances where the subjective implicit is also in the highest frequency. In fact, there are 9 probabilities, 17 usualities, 6 obligations and 13 inclinations in husband's utterances. The great number of usuality shows that the husband tried to express his indicative mood or his own thinking toward the problems discussed during divorce mediation and to respond other speakers' comments. The research also shows that the most significant of husband's orientation is subjective implicit with 29 data, followed by 16 data of subjective (explicit), 6 data of objective (explicit), and 6 data of objective (implicit). In addition, there are 28 low value, 11 median value and 19 high value modalities.

Otherwise, the researcher finds out that used only few modalities ( 8 data) since she was almost quite during the divorce mediation process, where the subjective implicit is also in the highest frequency (5 of 8 data). In fact, there are 3 probabilities, 1 usuality, 4 inclinations and no obligation in wife's utterances. The most frequent number of inclination shows that wife tried to express her imperative mood or what she wants from other speakers in relation to the problems discussed during divorce mediation. The research also shows that the most significant of wife's orientation is subjective implicit with 5 data, followed by 2 data of subjective (explicit), and 1 data of objective (implicit). In addition, there are 3 low value, 2 median value and 3 high value modalities.

There are several kinds of modalities used by the speakers in Indonesian divorce mediation. The most frequent modalities used by the speakers is low value. Under this category, each speaker shows his/her weak commitment/belief toward what s/he is saying and toward other speaker.

Table 1. Low value of modality used by Indonesian speakers

\begin{tabular}{ll}
\hline Speakers & Low value of modality \\
\hline Mediator & $\begin{array}{l}\text { Mungkin dia tidak kasi kamu karena dia tidak percaya sama kamu } \\
\text { (maybe he didn't give you the money because he didn't believe in you) }\end{array}$ \\
\hline Husband & $\begin{array}{l}\text { Pernah dia baku tengkar dengan bapakku } \\
\text { (She once got into a fight with my dad) }\end{array}$ \\
\hline Wife & $\begin{array}{l}\text { Dia kalo mauka beli-beli barang pasti marah } \\
\text { (if I want to buy goods, he certainly gets angry. }\end{array}$ \\
\hline
\end{tabular}


The table above shows three different sentences with different modal auxiliaries. First, the mediator used the word "mungkin" (maybe) to express the probability sense of modality. Through this sentence, the mediator expresses her feeling/thinking toward the wife's utterance about her husband who rarely gives her household expense. In the sentence, the mediator tried not to blame someone because of other's accusation, yet she implicitly tried to tell wife about her opinion on husband's thinking that he might not believe in her. She indirectly tells wife to be introspective of what her husband's done to her.

The second sentence is the utterance of husband describing his wife's attitude. He used the word "pernah" (ever) to express the usuality sense of modality. Through this sentence, the husband wanted to inform the mediator about one example of his wife's bad attitude that becoming one of the reasons why he proposed a divorce. He wanted to ensure the mediator that it is her who has behaved badly to his parents as she ever fought with his father.

The third sentence is the utterance of wife of her willingness to have some new goods. She used the word "mau" (want) to express the inclination sense of modality. Through this sentence, the wife intended to inform the mediator that it is only her willingness can cause madness of her husband. Since this inclination sense is a kind of imperative adjunct, she is trying to make the mediator can understand her situation and could also be a "weapon" to ruin her husband's credibility as the head of family who is responsible to fulfill family's necessity.

Table 2. Median Value of Modality used by Indonesian speakers

\begin{tabular}{ll}
\hline Speakers & Median value of modality \\
\hline Mediator & $\begin{array}{l}\text { Na digombal-gombal itu perempuan } \\
\text { (well, you just have to flatter the woman) }\end{array}$ \\
\hline Husband & $\begin{array}{l}\text { Memang, suka curiga dia. } \\
\text { (indeed, she likes to suspect) }\end{array}$ \\
\hline Wife & Siapatau justru nanti dapat yang lebih baik \\
& (who knows that I will get better person) \\
\hline
\end{tabular}

The table above shows only two different sentences with different modal auxiliaries. While the other one, the utterance of mediator, the modality exists in the repetitive verb: "na digombal-gombal". Although it is uttered in passive form, but based on the contex of speaking and the intonation of mediator, it means a suggestion for husband to just flatter his wife to win back her heart. That's why it is categorized as the obligation sense of modality in which reflecting imperative mood that is expressing idea to make the hearer/ other speaker understand and even do what she said.

The second sentence uttered by husband implies his belief toward his wife's attitude, that is she likes to suspect him in almost conditions. The word "like" has the same meaning with "keen" which indicates the inclination sense of modality. By this utterance, husband tried to express his idea with aiming to affect hearer, in this case the mediator.

The third sentence uttered by wife describes her hope or optimism toward future's fortune/luck, in terms of having better partner of life. She used the word "siapatau" (who knows) to express the probability sense of modality and also reflecting indicative mood in which she delivers her thought just for informing other speakers.

Table 3. High Value of Modality used by Indonesian speakers 
Andi Batari Andisa Putri. 1(2): 126-133

\begin{tabular}{ll}
\hline Speakers & High value of modality \\
\hline Mediator & $\begin{array}{l}\text { Baik, sekarang kita akan mulai proses mediasi antara bapak R dan ibu N } \\
\text { (well, we are going to start the mediation process between Mr. R and Mrs.) }\end{array}$ \\
\hline Husband & $\begin{array}{l}\text { Saya bilang janganko terlalu sering-sering melihat ke atas } \\
\text { (I always said not to look the rich family) }\end{array}$ \\
\hline Wife & $\begin{array}{l}\text { Saya mau (anak) ikut sama saya } \\
\text { (I want a custody) }\end{array}$ \\
\hline
\end{tabular}

The table above shows three different sentences with different modal auxiliaries. The first utterance is the utterance of mediator,in which the mediator used the word "akan" (going to) expressing the probability sense of modality with very strong belief and real step to conduct the divorce mediation, as the elements to conduct it has been fulfilled: the administration and the presence of spouses.

The second utterance is uttered by husband with modal auxiliary "terlalu seringsering" (always). It expressed the usuality sense of modality. Through this utterance, husband tried to tell the fact from his side that his wife also has worrying attitude that may cause the household financial problem. It is his wife who is too much demanding many things as the effect of seeing rich family's life style. By saying this, husband -again- tried to show the mediator the bad attitude of his wife in order to ruin his wife's character and to make the mediator understand the reason why he proposed a divorce.

The third utterance is uttered by wife with the word "mau" (want) with inclination sense of modality. It is a very strong willing and commitment of making the children join her. As she has taken them with her for many times staying with her parents, the children's grandparents. So, in this divorce mediation she is eager to tell and convince the mediator that it is she who really wants to have a formal/ official/institutional right to take care of their children (custody), not the husband.

\section{Discussion}

The universality of Haliday's theory is questioned in Indonesian language, especially when it merges to the dialect of South Sulawesi where the local language has affected the use of Indonesian language itself in which it can also affect the use of modal verbs in their utterance. Since the data of divorce mediation is collected in Masamba, (one of small town in South Sulawesi) there are some cases that the arrangement of words to form a sentence of Indonesian language is rather different. For instance, Indonesian language, the arrangement to form a sentence is subject+predicate, e.g :" Saya tidak bisa mempercayainya" (I can't believe in her), while people of South Sulawesi in common just say "tidak bisaka percaya-i" with arrangement : predicate+subject. The other example of cases can be seen in the use of two similar sentences "gombal itu perempuan!" and " na digombal-gombal itu perempuan". The first one is considered as an order while the other one is considered as suggestion. Those are some example of how the Indonesian language is uttered in South Sulawesi, as the place of collecting data.

In the Indonesian data, there are some cases found about the ambiguity of modality. One of the examples is the word "mau" (want) which is considered by Halliday to express inclination sense of modality. In fact, based on the context of Indonesian data, "mau" can also mean "akan" (will) expressing probability sense of modality as in the data "mauka 
pergi ambil I" (I will go take my kids). Besides, word "suka" which is categorized as inclination sense of modality can also mean "sering/biasanya/selalu" that indicates usuality sense of modality, as in the data "suka main-main hape" and "suka cemburu". The other phenomenon found in Indonesian data is the word "akan" (will) can have whether low or median or high value of modality. It again depends on context. When the speaker plans to do something, it is considered as low value. While when the speaker has arranged the plan well, it is considered as median value and when it is right at the moment to do it with all ready preparations, it is considered as high value.

In addition, In Indonesian divorce mediation, the topic is about reuniting the husband and wife who planned to have a divorce. It is a part of the formal process for husband and wife in a court and the mediator has a duty in giving a help to find the solution of their marriage problems. The mediator also mostly uses probability sense of modality to indicate the problem between husband and wife. She also tries to persuade them to rethink their plan to have a divorce and the condition of their children if they got divorced. Besides, she convinces them that their attitudes should be changed to safe their relationship.

\section{Conclusion}

The result of this research shows kinds of modalities used Indonesian speakers in divorce mediations discourse; specifically in the type, orientation, and the value of modality. The mediator mostly used probabilities and the wife mostly used inclinations. Besides, the mediator and husband mostly used low value modalities. Furthermore, in Indonesian divorce mediation discourse, the mediator, husband, and wife mostly used subjective-implicit. The topic discussed in Indonesian divorce mediation is about reuniting the husband and wife who planned to have a divorce.

This research shows that the use of Halliday's theory of modality is strongly affected by the context or social situation. The research needs to be improved by the next researchers in terms of innovations on developing Halliday's theory of Modality and the related theory such as Critical Discourse Analysis. The researcher also hopes that there will be more studies related to this object of research which can observe it deeper and more accurate.

\section{References}

Adawiah, Rabiatul. 2014. Modalities in Political Debate Discourse (A Thesis). Makassar: Hasanuddin University.

Badran, Dany. 2000. Ideology through Modality in Discourse Analysis (A Published Dissertation). United Kingdom: The University of Nottingham.

Casals, Miquel Martin. 2005. Divorce Mediation in Europe: An Introductory Outline. Electronic Journal Of Comparative Law, Vol. 92 (http://ejcl.org/., accessed on May 2016)

Gurbanova, Sevil Elchin. 2012. Verbs Expressing Wish and Their Modality Features in Modern English. International Journal of English Linguistics, Canadian Center of Science And Education; Vol. 2, No. 6. (www.ccsenet.org/ljel, accessed on April 2016)

Halliday, M.A.K. \& Matthiessen, Christian. 2004. An Introduction to Functional Grammar (3rd Edition). London: Arnold. 
Kristianto, Ayu Wulandari. 2014. Modality Use and Its Reflection On Power Relation: A Case of Indonesian Editorials in New Order Era. $\quad$ (http://dx.doi.org/10.15242/icehm.ed0514071 98, accessed on March 2016)

Kruk, Edward. 1998. Imbalance and Spouse Abuse in Divorce Disputes: Deconstructing Mediation Practice via the 'Simulated Client' Technique. International Journal of Law, Policy and the Family 12, 1-14

Rahman. 2015. Struktur Skematis dan Modalitas dalam Wacana Ceramah Sanusi Baco, LC (A Thesis). Makassar: Hasanuddin University.

Roth, Stephanie S. 2014. Power, Politics, and Gender-Related Epistemic Modality in Interview Discourse: A Case Study of TV/Video Interviews with Canadian Politicians. Canada: University Of Gothenburg

Spradley, James P. 1980. Participant Observation. USA : Holt, Rinehart \& Winston

Sugiono. 2013. Metode Penelitian Kuantitatif Kualitatif dan R\&D. Bandung: CV. Alfabeta.

Yule, George. 1996. The Study of Language. Cambridge: Cambridge University Press 